\title{
SONORIDADES AFRO-BRASILEIRAS EM CORUMBÁ: UM ESTUDO SOBRE REPRESENTAÇÕES MUSICAIS EM RITUAIS DE UMBANDA
}

\author{
Carmem Silvia Moretzsohn Rocha ${ }^{12}$
}

\section{Introdução}

Na relação entre antropologia e música, Seeger (Velho, 1977: 39) afirma que existem dois grupos de etnomusicólogos: os que se preocupam com "a relação entre a música e a sociedade que a produz" e aqueles que se voltam para "o estudo dos sons musicais em si" (Velho, 1977: 39). Em sua obra clássica, "Por que os índios Suya cantam para as suas irmãs?", procura trabalhar com as duas concepções de forma complementar. Inspirado no conceito de fato social total de Marcel Mauss, o autor chama a atenção para "a importância do acontecimento musical total", em que é preciso observar todo o contexto em que a manifestação musical ocorre a fim de compreender mais profundamente seus significados (Velho, 1977: 45).

No processo de observação, o antropólogo deve, segundo o referido autor, privilegiar a audição sem abrir mão de sua visão que é capaz de registrar os eventos concomitantes que contextualizam a manifestação musical. Dessa forma, será possível analisar a cosmologia e a organização social do grupo estudado. A primeira parte do trabalho do pesquisador é a descrição do fenômeno estudado representado pela pergunta: “o que eles estão fazendo?”, e a segunda, uma análise que se constitui na questão: "por que eles a fazem desta maneira?" (Velho, 1977: 39). Segundo Oliveira Pinto (2001),

Música é manifestação de crenças, de identidades, é universal quanto à sua existência e importância em qualquer que seja a sociedade. Ao mesmo tempo é singular e de difícil tradução, quando apresentada fora de seu contexto ou de seu meio cultural.

(Oliveira Pinto, 2001: 3)

Partindo desses pressupostos teórico-metodológicos, o objetivo da presente pesquisa é abordar o universo sonoro em rituais de Umbanda como crucial e constitutivo dessas manifestações religiosas. As perguntas fundamentais que motivam

\footnotetext{
${ }^{1}$ Universidade do Estado do Rio de Janeiro, Brasil.

${ }^{2}$ Doutoranda em Ciências Sociais pela Universidade do Estado do Rio de Janeiro, Brasil. Professora de Sociologia do Instituto Federal de Mato Grosso do Sul - Campus Corumbá, Brasil. Mestre em Ciências Sociais pela Universidade do Estado do Rio de Janeiro, Brasil.
} 
este estudo são: como se organizam os aspectos sonoros durante esses rituais? De que forma revelam a cosmologia da Umbanda e dialogam com a complexa gama de gestos, procedimentos, cores, imagens, enfim, todo o contexto em que estão inseridos? Como os personagens envolvidos se relacionam com suas práticas musicais e o que pensam a respeito?

A hipótese subjacente ao processo de investigação em que nos lançamos é de que a curimba $^{3}$, presente nos rituais a que nos referimos, está repleta de aspectos pertencentes ao imaginário da identidade negra ou negritude, de maneira a reafirmá-la, integrando sua cosmologia. Para tanto, abordaremos o debate sobre os significados desse universo simbólico, a complexidade desse conceito e, ainda, as imbricadas relações que estabelecem com outras searas, como, por exemplo, os laços familiares com ascendentes escravos negros, a relação com o movimento negro e a questão dos quilombolas. Embora constitua tarefa inexequível abordar todos esses campos de estudo de forma aprofundada, por constituírem áreas autônomas de pesquisa, faz-se necessário tocar nesses pontos, posto que surgiram no decorrer do próprio trabalho de campo, iniciado em junho de 2011.

Esta pesquisa apresenta algumas particularidades que acreditamos ser profícuas aos campos de estudo que integra. Os pontos cantados da Umbanda são, geralmente, transmitidos oralmente, e o registro das letras e, menos ainda, dos elementos musicais não constitui uma prática recorrente da maioria dos antropólogos, apesar de estar, atualmente, em franca expansão. Além disso, o principal terreiro onde foi realizada a observação participante é situado em uma comunidade quilombola. Esse aspecto representou um elemento significativo na relação desse terreiro com a noção de identidade negra, cultivada conscientemente pelo grupo.

Ademais, a pesquisa acerca das religiões afro-brasileiras aparece inúmeras vezes na literatura com enfoque regional, como, por exemplo: o tambor de mina maranhense (Ferreti, 1986; Ferreti, 1993), o xangô pernambucano (Ribeiro, 1952; Motta, 1988; Carvalho, 1984; Segato, 1995), o batuque gaúcho (Corrêa, 1992; Oro, 1994), o candomblé baiano (Rodrigues, 1935; Bastide, 1978; Verger, 1981), o candomblé carioca (Conduru, 2010; Rio, 2006), o candomblé paulista (Amaral, 1992; Silva, 1995). Como se pode constatar, o Estado do Mato Grosso do Sul não figura entre os mais pesquisados no que concerne ao estudo dessas religiões. Porém, tanto a presença de

\footnotetext{
${ }^{3}$ Curimba e corimba são sinônimos e significam "cântico religioso afro-brasileiro" (Lopes, 2006: 84).
} 
afrodescendentes quanto os seguidores das chamadas religiões de matrizes africanas são significativos nesse território. ${ }^{4}$ Vale ressaltar que o professor Gustavo Villela, antropólogo e único professor de antropologia da Universidade Federal de Mato Grosso do Sul - Campus Pantanal, situada em Corumbá, declarou-me no dia 23 de março de 2012 que não existem pesquisas antropológicas consistentes realizadas na cidade e, portanto, qualquer estudo a realizado contém caráter inédito.

Para esta pesquisa qualitativa, além da observação participante e das entrevistas semi-abertas com importantes personagens dos rituais de Umbanda, foram tiradas fotografias e feitas gravações em áudio e filmagens a fim de registrarmos o máximo de informações em diferentes tipos de mídias. O objetivo foi enriquecer o diário de campo e criar um acervo que poderá ser útil a outros pesquisadores e, ainda, viabilizar o desdobramento desta pesquisa em outras produções que possam abarcar, por exemplo, o campo da antropologia visual. Por fim, serão inseridos ao corpo desta tese em construção o registro de parte das letras e músicas coletadas tanto no campo quanto nas entrevistas, especialmente as que estão relacionadas ao tema da identidade negra.

\section{Corumbá, locus da pesquisa}

Segundo a matéria Capital do Pantanal, publicada no Jornal On Line, em 17 de novembro de 2011, Ednir de Paulo, presidenta do Instituto da Mulher Negra do Pantanal (IMNEGRA), afirmou que os afrodescendentes representam $71 \%$ da população de Corumbá. No mapa abaixo, é possível perceber que, segundo o IBGE, há uma concentração de pretos e pardos entre 60 e $80 \%$ da população.

$$
* * *
$$

\footnotetext{
${ }^{4}$ Após sofrer uma mudança de curso - originalmente meu projeto para o doutorado seria um aprofundamento de minha dissertação de mestrado sobre cotas raciais no Rio de Janeiro - decidi, com apoio de minha orientadora Márcia Contins, investigar os meandros do universo sonoro em terreiros de Umbanda. No terceiro ano do curso, vivi uma profunda angústia: a de ser obrigada a levar o meu estudo para a futura residência, a saber, a cidade de Corumbá, situada no Estado de Mato Grosso do Sul. Ignorava a viabilidade de realizar minha pesquisa nessa cidade. Pouco a pouco, fui me dando conta que o desafio descortinava-se em grande oportunidade: a de adentrar um campo pouco estudado.
} 


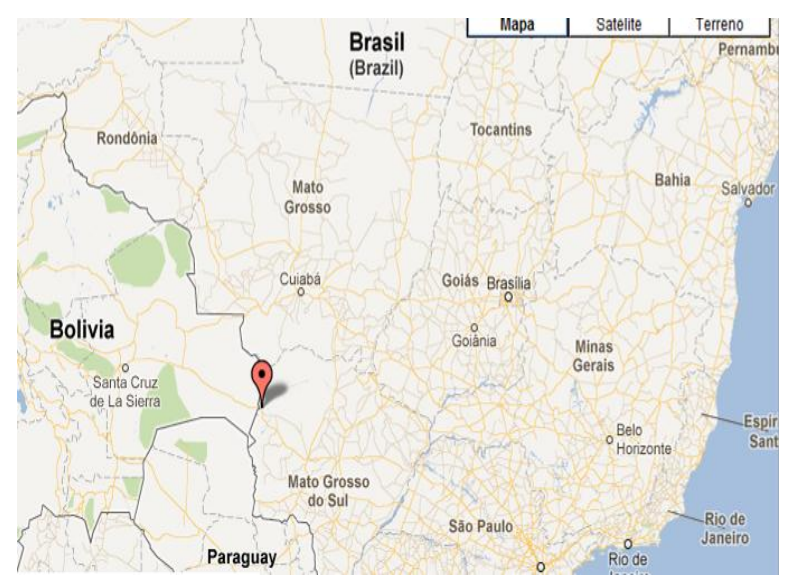

Figura 1 - Localização de Corumbá. Fonte: http://maps.peeplo.com/?q=atlas+brasil

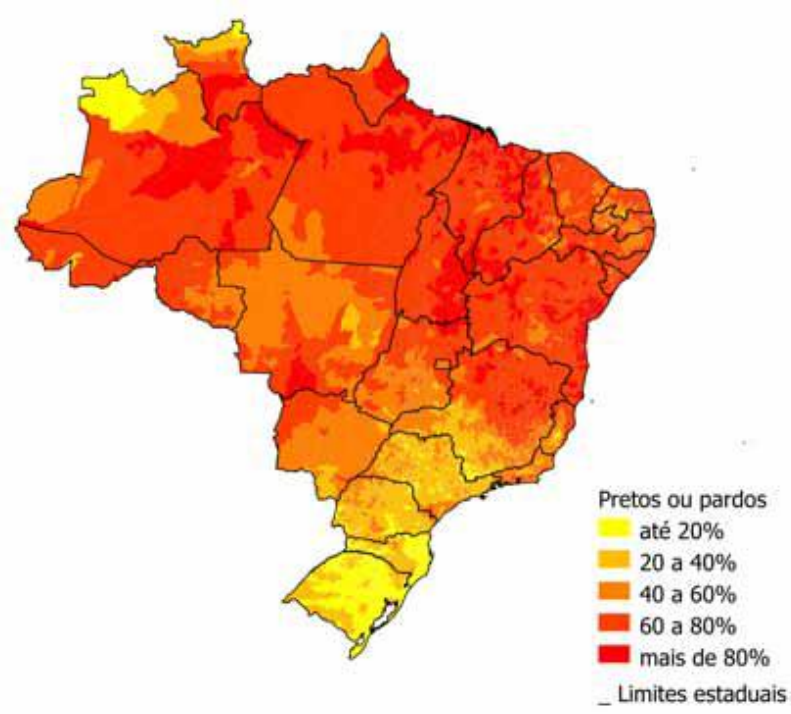

Figura 2 - Distribuição da população de cor ou raça preta e parda - Brasil. Fonte: IBGE, Censo Demográfico 2010.

O município de Corumbá abriga um contingente significativo de frequentadores de religiões do tipo supracitado. Em box explicativo sobre etnobotânica e o uso das plantas medicinais (ewé), nas religiões de matriz afrodescendente presente no Relatório Anual das Desigualdades Raciais 2009-2010 é citada uma pesquisa realizada no município pantaneiro de Corumbá (MS), onde foram mencionadas "49 plantas utilizadas, sendo $24,5 \%$ usadas com exclusiva finalidade medicinal e outras $25,5 \%$ com 
finalidades medicinais e litúrgicas" (Tucan e col., 2004: 52). Esse fato corrobora a constatação de que em relação à religiosidade "afro-brasileira", $0,26 \%$ da população de Mato Grosso do Sul declarou pertencer a esse grupo, ficando logo após da Bahia, território que se destaca nesse campo, ocupando o quinto lugar no ranking dos Estados, segundo o Novo Mapa das Religiões, publicado pelo Centro de Políticas Sociais da Fundação Getúlio Vargas (CPS/FGV) em 2011. Os três primeiros são: Rio de Janeiro, Rio Grande do Sul e São Paulo. Quanto à distribuição dos adeptos de religiões afrobrasileiras entre as regiões do País, esse mesmo documento apresenta 0,56\% no Sudeste; $0,43 \%$ no Sul; $0,14 \%$ na Região Nordeste; $0,11 \%$ no Centro-Oeste e $0,07 \%$ no Norte do Brasil.

Através do site do CPS/FGV podemos obter uma lista resultante do processamento dos microdados do Censo Demográfico 2000/IBGE Mapa das Religiões publicado pelo Centro de Políticas Sociais da Fundação Getúlio Vargas (CPS/FGV) ${ }^{5}$ e observar que, entre os 5.507 municípios onde seus habitantes autodeclaram-se afrodescendentes, Corumbá é o $144^{\circ}$ município, enquanto Salvador - cidade relevante no imaginário popular e na literatura acadêmica sobre o tema - figura em $172^{\text {o. }}$ lugar. Além disso, a cidade ocupa o primeiro lugar entre os municípios do Estado de Mato Grosso do Sul nesse quesito. Ainda a fim de ressaltar a importância de Corumbá para o universo pesquisado, foi revelado em entrevista com um famoso pai de santo local que a cidade tem aproximadamente 300 terreiros de umbanda ou candomblé. No Jornal Correio do Estado On Line lê-se: "Com 25 anos de existência, a Federação dos cultos afro-brasileiros e ameríndios de Mato Grosso do Sul (FECAMS), afirma que em Campo Grande existem 600 terreiros registrados e em Corumbá o número chega a 1.200". Aceitar essa estimativa como correta significa que, para uma população de aproximadamente 100.000 habitantes, haveria um terreiro de umbanda ou candomblé para cada 83 indivíduos. Abaixo, temos um mapa da cidade acrescido de algumas características e dados estatísticos disponibilizados no site da prefeitura do município.

\footnotetext{
${ }^{5}$ http://www.fgv.br/cps/religiao
} 


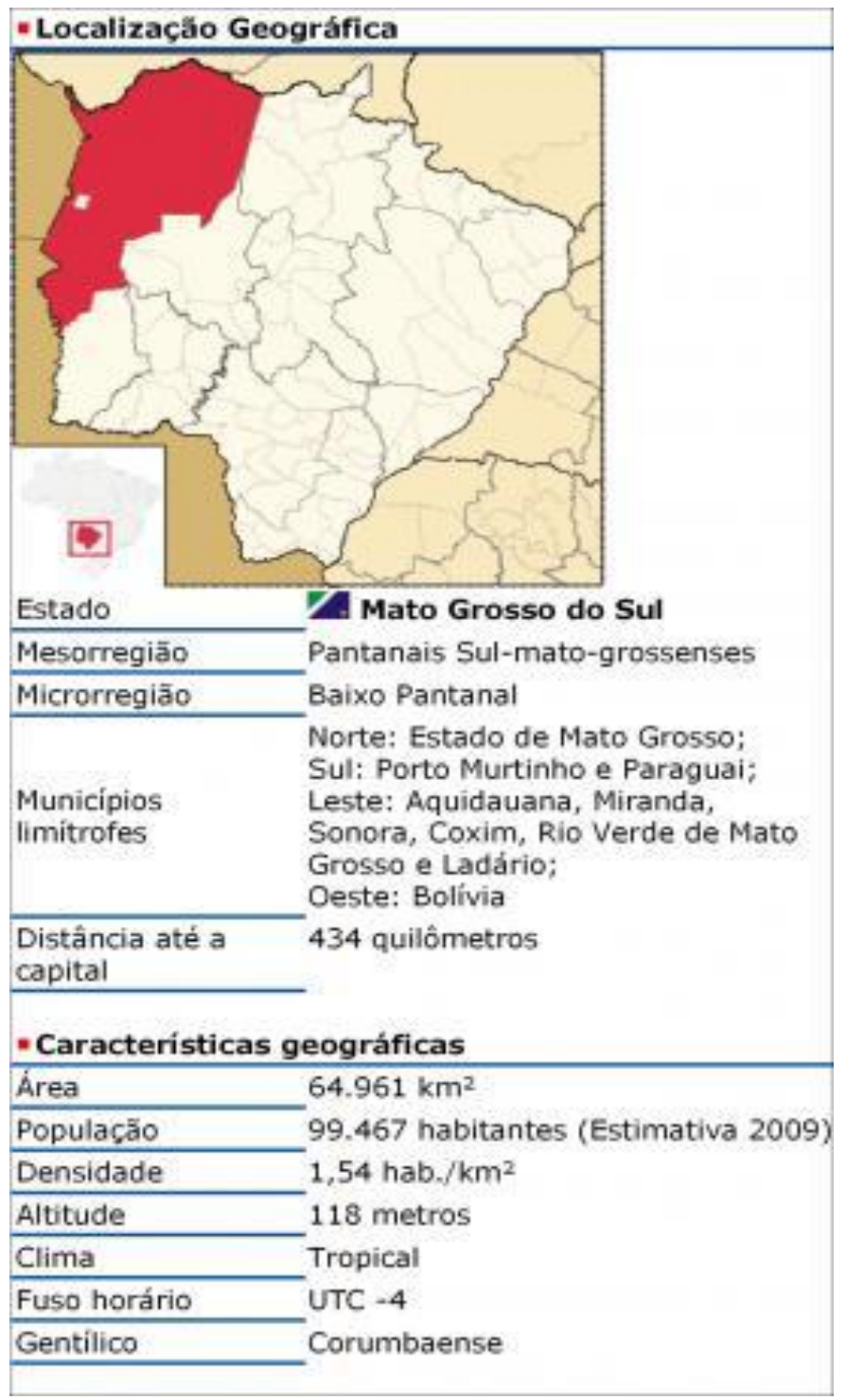

Figura 3 - Mapa de Corumbá.

Fonte: http://pt.wikipedia.org/wiki/Corumb\%C3\%A1 


\section{Antecedentes e metodologia da pesquisa}

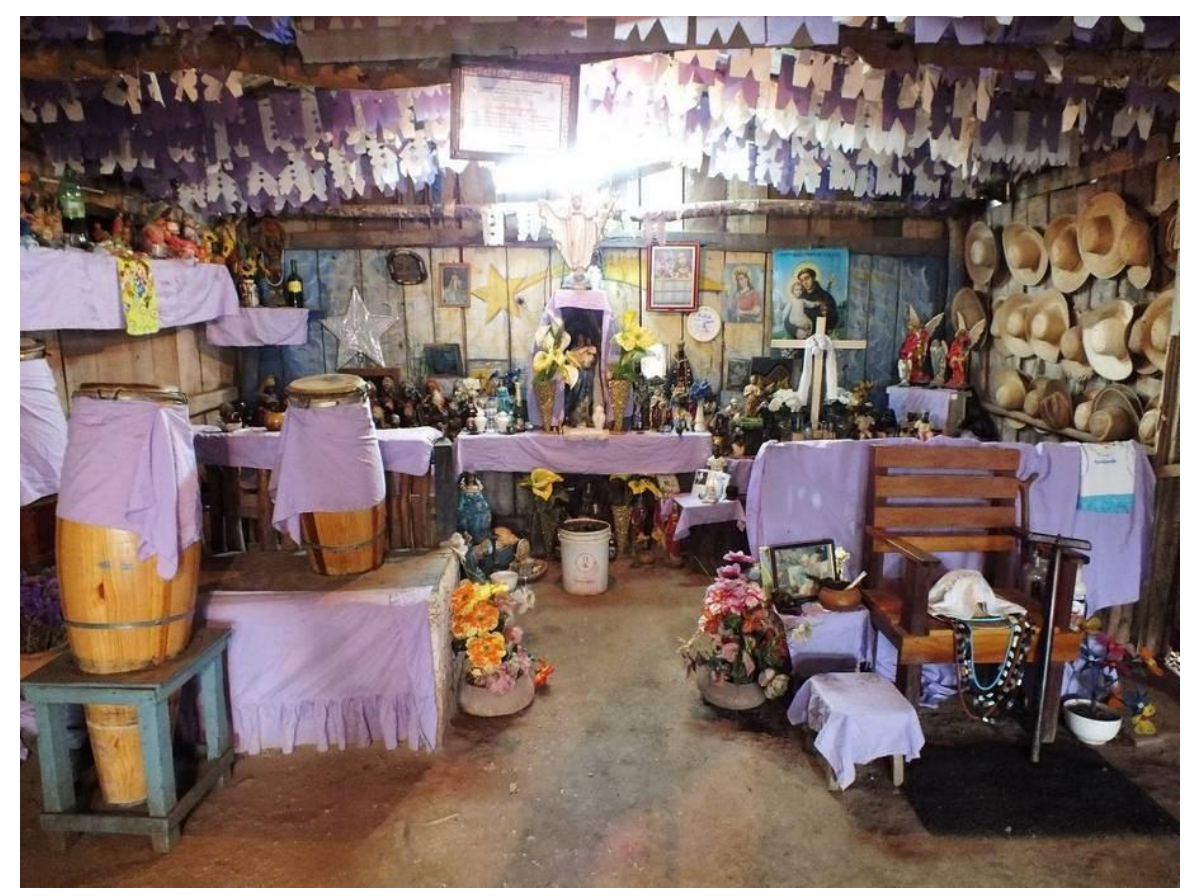

Figura 4 - Visão frontal da "Tenda” (Corumbá, 09/09/2011). Foto: Carmem Silvia Moretzsohn Rocha.

Conciliar acasos e intenções, esforços, constrangimentos, dúvidas, realizações, angústias em um universo de magia e, ao mesmo tempo, organização de complexos elementos materiais e simbólicos constitui um dos desafios desta pesquisa de doutorado sobre as sonoridades afro-brasileiras.

Paulatinamente, decidimos focalizar um famoso terreiro de Umbanda da cidade de Corumbá para realizar uma observação participante. Alguns personagens e fatos, juntos, desencadearam esse processo. Em primeiro lugar, ao chegar a Corumbá, no dia 3 de junho de 2011, conheci Daniel ${ }^{6}$ e fui convidada por ele a conhecer a Tenda ${ }^{7}$, o que representou um fato fundamental para a minha entrada no campo. Além disso, Daniel

\footnotetext{
${ }^{6}$ Utilizarei nomes fictícios a fim de preservar o anonimato dos indivíduos citados, exceto no caso de Ednir de Paulo, reconhecidamente presidenta do Instituto da Mulher Negra do Pantanal (IMNEGRA). Ednir é uma importante articuladora do movimento negro em Corumbá e participa ativamente do processo de reconhecimento das comunidades quilombolas, assim como dos mais variados eventos desta seara.

${ }^{7}$ Daniel é um dos fundadores da Tenda, sinônimo de terreiro, que significa o local onde ocorre a maioria dos rituais. Referir-me-ei desta forma para não revelar a identidade do grupo pesquisado, já que, geralmente, cada terreiro tem seu nome.
} 
também concordou em conceder-me uma entrevista, a primeira de todas, que ocorreu no dia 10 de junho do mesmo ano e teve a duração de aproximadamente três horas. Ainda fui convidada para a festa de Santo Antônio que, segundo ele, era conhecido na Umbanda como "Exu ${ }^{8}$, o orixá ${ }^{9}$ responsável pela comunicação entre os homens e os orixás".

Na obra $O$ antropólogo e sua magia, dedicada especificamente ao trabalho de campo sobre religiões afro-brasileiras, Silva chama a atenção para as peculiaridades da observação participante realizada em terreiros: "as dificuldades no estudo de uma religião duramente perseguida durante anos, iniciática, de transe, com uma especial visão da relação entre poder e conhecimento" (Silva, 2006: 15).

É importante levar em conta as metamorfoses sofridas pelo método da observação participante desde os tempos de Malinowski até o mundo contemporâneo. Clifford nos lembra que é preciso, no processo da referida metodologia, "resistir ao impulso de representar o outro de forma autolegitimadora" (Clifford, 2011: 44). O autor afirma que, "entendida de modo literal, a observação participante é uma fórmula paradoxal e enganosa, mas pode ser considerada seriamente se reformulada em termos hermenêuticos, como uma dialética entre experiência e interpretação" (Clifford, ibidem: 32). Segundo o autor, a noção tradicional de que a etnografia é capaz de traduzir de forma perfeita a alteridade da cultura estudada não é possível em função da interferência da subjetividade do pesquisador. No entanto, se levarmos em consideração o caráter interpretativo do método, podemos reconhecê-lo como válido.

$\mathrm{O}$ aspecto polifônico dessa metodologia também deve ser levado em conta:

\footnotetext{
${ }^{8}$ Exu, segundo Maggie, trata-se de uma "Entidade que representa o bem e o mal. Algumas vezes é identificado com o Diabo. Sua imagem de cerâmica representa um homem com pés de bode, orelhas pontiagudas segurando às vezes um tridente, vestido muitas vezes com capa preta ou vermelha e usando cartola. Outras vezes são homens de peito nu. Os Exus, quando estão no terreiro, dizem palavrões e fazem gestos obscenos, dão gritos lancinantes e gargalhadas estridentes. Sua figura é ambígua, pois, podendo fazer o bem e o mal, tornam-se perigosos e poderosos. A relação dos homens com os Exus é quase sempre um risco porque eles podem trapacear seus filhos, dizendo uma coisa e fazendo outra. Os Exus são os donos das encruzilhadas e do cemitério, onde são depositadas oferendas" (Maggie, 1975: 161).

9 "A religião dos orixás está ligada à noção de família. A família numerosa, originária de um mesmo antepassado, que engloba os vivos e os mortos. O orixá seria, em princípio, um ancestral divinizado, que, em vida, estabelecera vínculos que lhe garantiam um controle sobre certas forças da natureza, como o trovão, o vento, as águas doces ou salgadas, ou, então, assegurando-lhe a possibilidade de exercer certas atividades, como a caça, o trabalho com metais ou, ainda, adquirindo o conhecimento das propriedades das plantas e de sua utilização. O poder, àse, do ancestral-orixá teria, após a sua morte, a faculdade de encarnar-se momentaneamente em um de seus descendentes durante um fenômeno de possessão por ele provocada" (Verger, 1981: 18).
} 
O diálogo ficcional é de fato uma condensação, uma representação simplificada de complexos processos multivocais. Uma maneira alternativa de representar essa complexidade discursiva é entender o curso geral da pesquisa como uma negociação em andamento.

(Clifford, ibidem: 44)

No caso desta pesquisa, pude perceber que em minha entrevista com Daniel havia, pelo menos, quatro personagens. Enquanto discorria sobre o mundo espiritual, comentou que havia uma entidade ${ }^{10}$ próxima a ele orientando sua fala e, ao mesmo tempo, eu considerava a presença de minha orientadora em meus procedimentos. Nesse momento, além de mim e Daniel, tínhamos dois mentores contribuindo para o diálogo estabelecido. Se levarmos em conta outros atores do mundo espiritual representado pela entidade mencionada por Daniel e da comunidade acadêmica em que me vi inserida, podemos perceber a polifonia descrita por Clifford exemplificada nesse contexto.

Após passar pelo ritual acadêmico da Qualificação em agosto de 2011 na UERJ, voltei a Corumbá e fui apresentada por Daniel ao pai de santo responsável pela Tenda, em 9 de setembro do mesmo ano. Tive, então, permissão para frequentar a casa que era igualmente sua residência (seu quarto fica logo atrás do local onde ocorrem os trabalhos $^{11}$ ).

Podemos dizer que o trabalho de campo teve dois marcos iniciais. O primeiro, no dia 3 de junho de 2011, quando conheci Daniel, que me levaria à "Tenda", e antes de minha Qualificação; o segundo, após esse evento acadêmico, teve início no dia 9 de setembro de 2011 (figura 4), quando conheci o pai de santo desse terreiro e obtive sua permissão para realizar a pesquisa. Neste estudo, que se encontra em andamento, podemos considerar que o último evento do trabalho de campo foi a visita no dia do aniversário do pai de santo, 21 de setembro do presente ano. Do primeiro encontro ao último evento, temos um ano e três meses decorridos. Neste período, foi possível reunir um acervo com 4.537 fotografias; 493 vídeos, totalizando 33 horas, 59 minutos e 17 segundos, gravados em 27 eventos e 9 entrevistas que, por sua vez, somaram 12 horas, 19 minutos e 01 segundo gravadas. Atualmente, debruçamo-nos sobre esse material com o intuito de análise e construção da tese de doutoramento.

\footnotetext{
${ }^{10}$ Entidade: "Espíritos. Os Orixás. As figuras do sobrenatural" (Maggie, 1975: 161).

${ }^{11}$ Rituais que as pessoas da comunidade frequentam e onde ocorrem os passes, aconselhamentos, curas e desobsessões. Por meio do passe, a entidade incorporada em um médium transmite fluidos a uma pessoa com o objetivo de curar ou auxiliá-la em seu equilíbrio vital. Embora a palavra desobsessão não exista no dicionário Houaiss, ela está presente na linguagem popular e significa afastar o(s) espírito(s) que persegue $(\mathrm{m})$ alguém. Esse procedimento, também chamado de "transporte", é realizado durante os rituais com a ajuda dos médiuns. Muitas vezes, existe um dia e um momento específico da sessão.
} 
Amaral e Silva defendem o uso de variadas tecnologias na pesquisa das religiões afro-brasileiras: "Acreditamos, assim, que a etnografia em hipermídia por permitir interpretar o fluxo do discurso social em seus múltiplos planos inter-relacionados tem potencialidades inexploradas no sentido de realizar o objetivo da etnografia (...)" (Amaral e Silva, 2006: 111). O objetivo das fotografias e vídeos foi, em primeiro lugar, construir um diário de campo o mais rico possível, pois poder retornar aos eventos por meio deles auxilia muito na construção da tese. Como já mencionado, tive a intenção de criar um acervo e, ainda, abrir portas para desdobramentos da pesquisa em outros tipos de produção científica e/ou artística. $\mathrm{O}$ foco na música também influenciou a decisão de gravar de múltiplas formas que interagissem posteriormente na compreensão e transcrição dos fenômenos. O próprio ato de fotografar e filmar ajuda também na interação com os grupos que, visivelmente, sentem-se valorizados. Silva (op. cit.) relata que "o registro de eventos rituais através de máquinas fotográficas e de filmadoras de vídeo já se tornou comum nas religiões afro-brasileiras, e vem sendo feito não apenas por pesquisadores dos terreiros, mas também pelos próprios religiosos" (Silva, ibidem: 63). Ainda sobre esses recursos, afirma que

Na prática atual da etnografia, a utilização de gravadores de som e de filmadoras tem possibilitado ao pesquisador registrar falas, situações e imagens dos seus interlocutores de forma mais detalhada se comparada com o registro por anotações feitas na hora ou de memória. A capacidade desses recursos de capturar com fidelidade imagens e sons não se confunde, porém, com uma maior "aproximação do real”, pois, ao filmar ou gravar, o pesquisador já seleciona entre as inúmeras possibilidades aquilo que ele deseja ver e ouvir, seja no momento em que os fatos se desenvolvem, seja posteriormente ao selecionar quais partes desses registros serão significativas para a sua interpretação.

(Silva, ibidem: 59)

No caso do presente estudo, buscamos captar o máximo de informações possível dos eventos presenciados, voltando nossa atenção tanto para o pai de santo, como para os ogans e médiuns. Geralmente, não fotografava ou filmava a assistência a fim de não constranger os que foram procurar ajuda espiritual na casa. No processo de seleção em andamento, buscamos nos orientar pelos dois principais eixos da pesquisa, a saber, as sonoridades envolvidas nos rituais e representações do universo da identidade negra.

É interessante notar que as representações de negritude perpassam diversos aspectos e, apesar de não podermos essencializar nenhum deles, é possível captar significados que se entrelaçam, se afastam ou se aproximam de acordo com valores e interesses de determinados indivíduos ou grupos sociais. Bernd esclarece que o termo 
negritude surgiu há aproximadamente setenta anos na França e seus múltiplos significados foram listados em um artigo de Lylian Kesteloot (1973) e, segundo a autora, "pode remeter: ao fato de se pertencer à raça negra; à própria raça enquanto coletividade; à consciência e à reivindicação do homem negro civilizado; à característica de um estilo artístico ou literário; ao conjunto de valores da civilização africana" (Bernd, 1988: 16).

\section{Segundo Contins,}

Os símbolos ligados à pele branca não necessariamente tornam-se indesejáveis, mas os símbolos da pele negra podem passar à condição de desejáveis. Ser negro enquanto parte de uma raça é indesejável e considerado inferior, mas enquanto parte de um grupo étnico seria bom, na medida em que faz parte de um grupo coeso, que é visto como ativo e anula as desvantagens de seu status de minoria (Contins, 2008: 95).

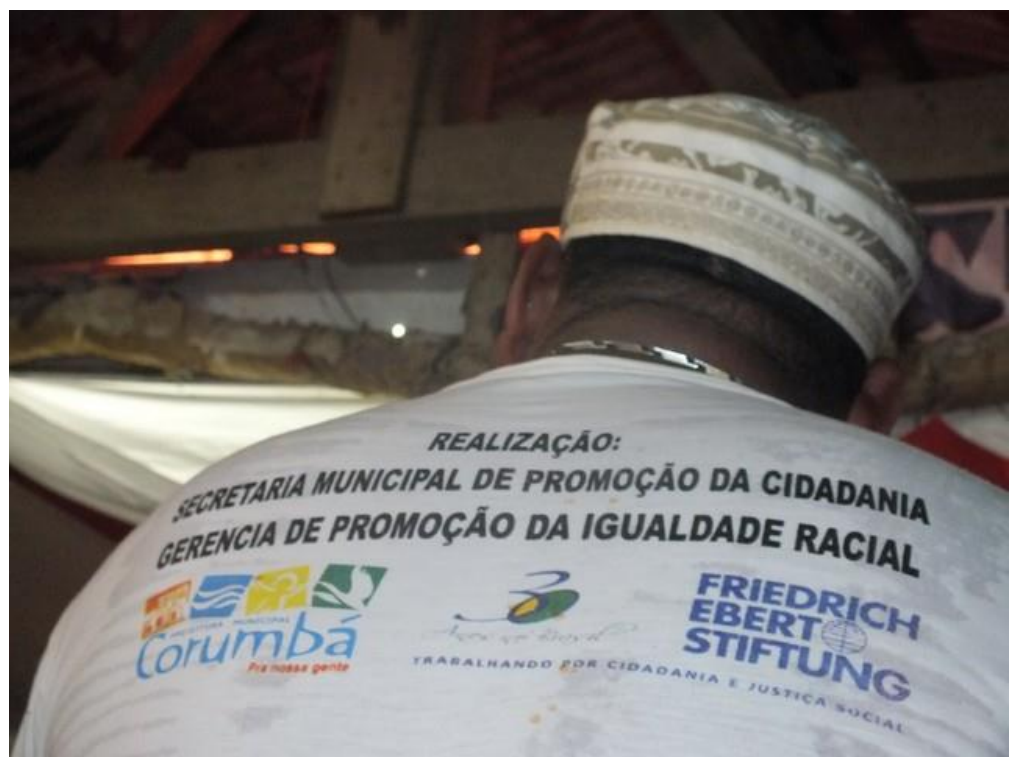

Figura 5 - Visão posterior da camiseta do ogan da "Tenda", tocando durante a Festa de Ogum. (Corumbá, 23/04/2012). Foto: Carmem Silvia Moretzsohn Rocha.

Podemos notar na foto acima que o ogan vestiu uma camiseta em que afirma conscientemente a identidade negra em um importante evento público de sua religião de matriz africana. Os indivíduos entrevistados eram personagens de destaque como pais 
de santo e líderes no que tange às curimbas, os ogans ou cambones ${ }^{12}$, responsáveis por puxar os pontos, ou seja, iniciar o canto das toadas.

\section{Resultados preliminares: universo sonoro e etnicidade na Umbanda}

No processo de observação participante e nas entrevistas realizadas com os adeptos de Umbanda, percebemos a nítida articulação entre aspectos da identidade negra, a Umbanda e os pontos cantados. Nesta pesquisa, o foco são os elementos sonoros inseridos na cosmologia umbandista e o diálogo com outras manifestações que afirmam a negritude, tais como o movimento negro e as comunidades quilombolas. É possível notar, ainda, a constante exaltação de universos simbólicos tanto de negros quanto de índios representados por falanges ${ }^{13}$ de caboclos ${ }^{14}$ e pretos velhos ${ }^{15}$. A própria Federação dos Cultos Afro-Brasileiros e Ameríndios de Mato Grosso do Sul (FECAMS) tem em seu nome ambas as referências.

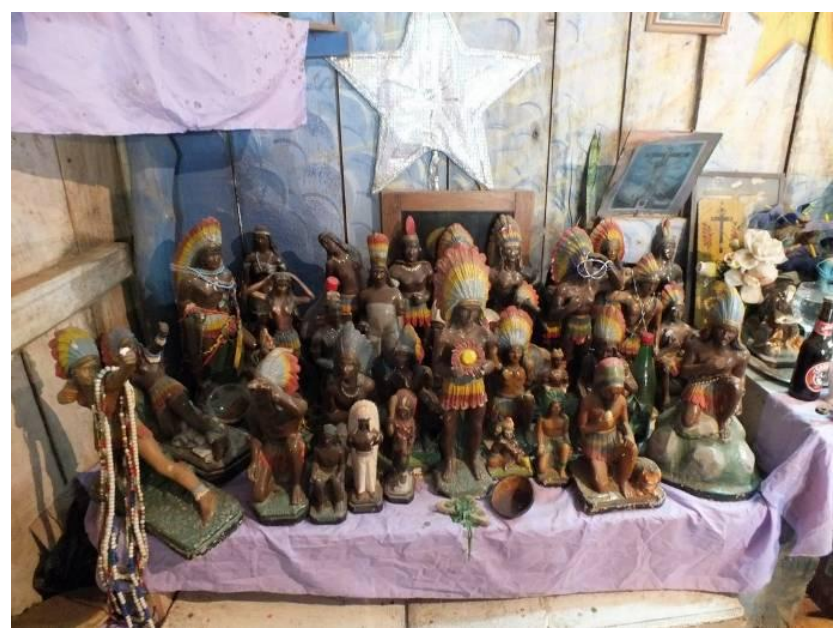

Figura 6 - Ala dos caboclos. (Corumbá, “Tenda”, 09/09/2011). Foto: Carmem Silvia Moretzsohn Rocha.

\footnotetext{
12 Cambone ou cambono: "auxiliar de pai-de-santo, na Umbanda" (Lopes, ibidem: 60).

$13 \mathrm{Na}$ Umbanda, conjunto de entidades espirituais que agem dentro de uma mesma linha ('faixa de vibração') (Dicionário eletrônico Houaiss da língua portuguesa).

${ }^{14}$ Entidades que representam índios e também figuras do campo como, por exemplo, o boiadeiro. São também chamados de Oxosse, o deus da guerra da mitologia africana e são associados ao Santo Católico Sebastião, o padroeiro da cidade do Rio de Janeiro. Sua imagem de cerâmica representa um índio ou índia de torso nu, pintada de uma cor amarronzada com cocares e arcos ou flechas. Recebem nomes indígenas como o Caboclo Irapuã e a Cabocla Jurema (Maggie, ibidem: 159).

${ }^{15}$ Entidades que representam velhos e velhas pretas. São velhos ex-escravos (vovôs e vovós ou tios e tias) que andam curvados, algumas vezes apoiados em bengalas e falam errado. Esses ex-escravos teriam sido velhos feiticeiros ou velhos guerreiros. Sua imagem de cerâmica representa um velho ou velha preta com os cabelos brancos e roupas rústicas brancas, sempre fumando um cachimbo (Maggie, ibidem: 167).
} 


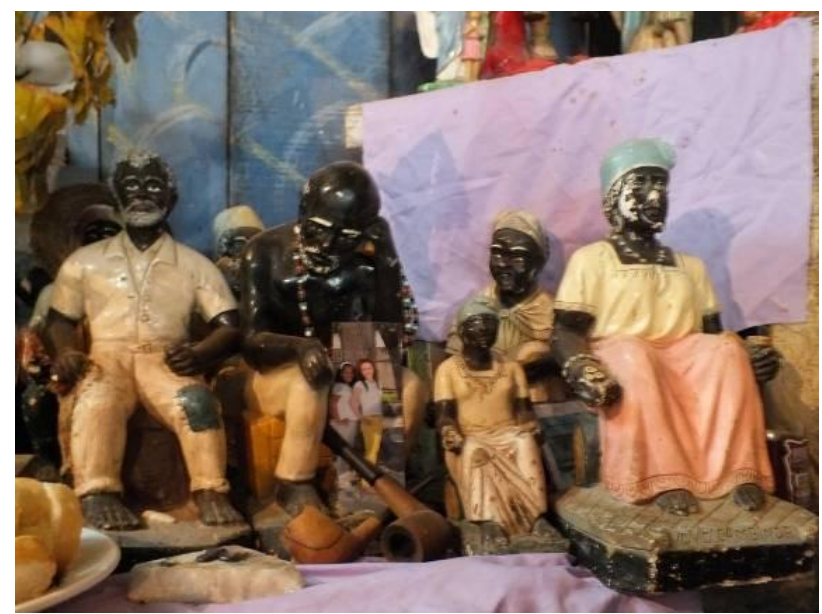

Figura 7 - Ala dos pretos velhos. (Corumbá, “Tenda”, 09/09/2011). Foto: Carmem Silvia Moretzsohn Rocha.

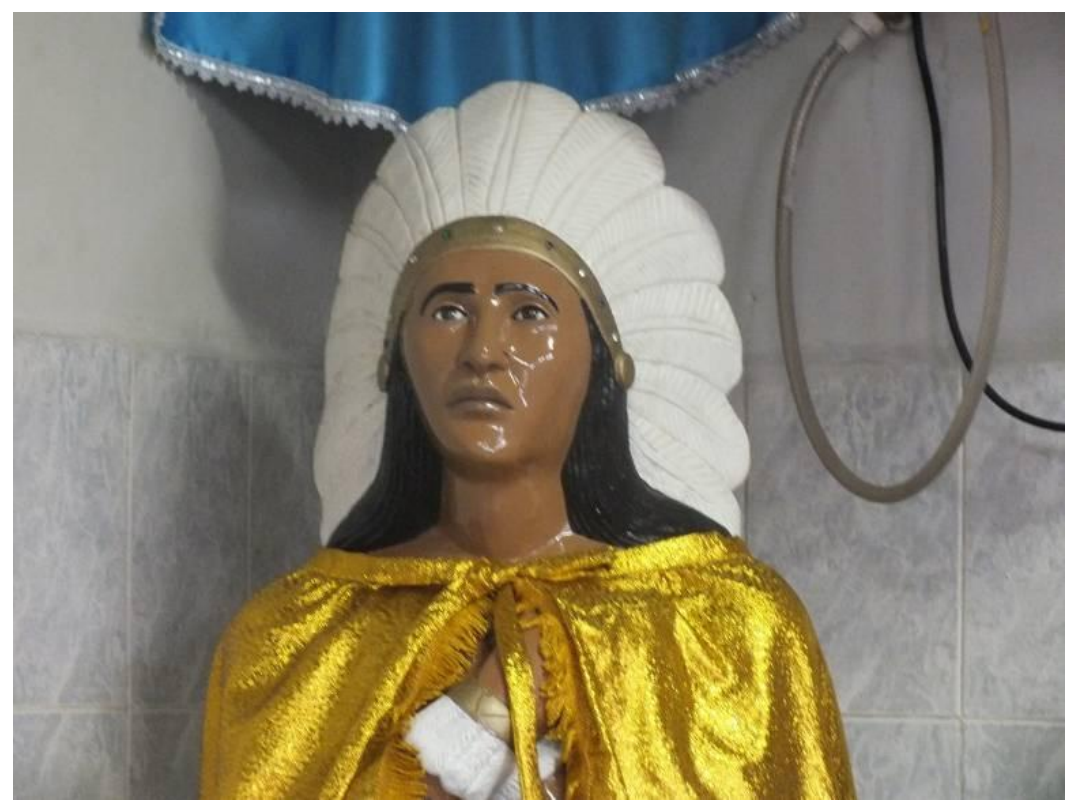

Figura 8 - Caboclo Pena Branca. (Corumbá, terreiro do Pai André, 03/03/2012). Foto: Carmem Sílvia Moretzsohn Rocha. 


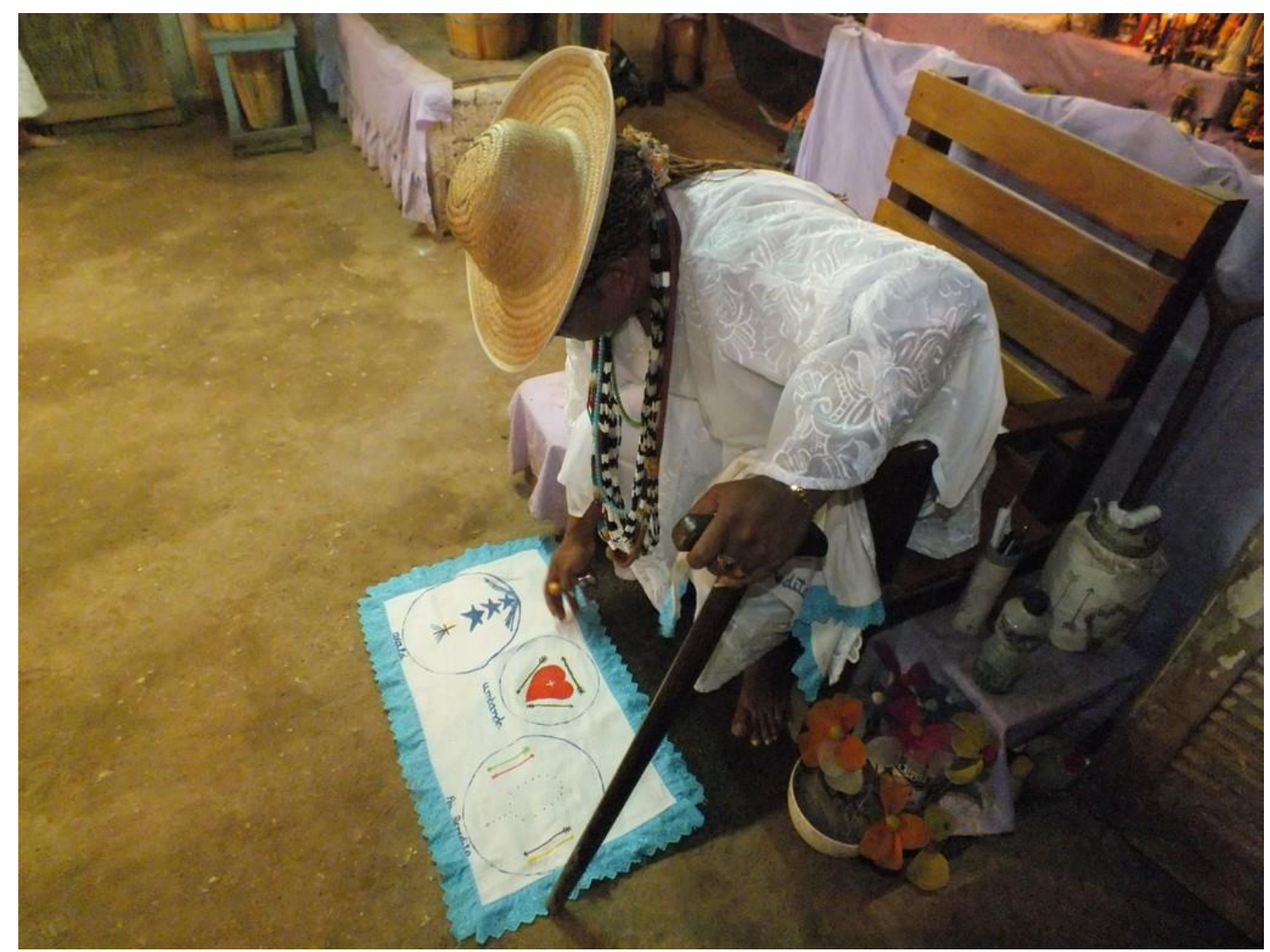

Figura 9 - Pai Benedito (preto velho e chefe espiritual da "Tenda") incorporado. Neste momento, os médiuns colocam-se em fila para receber sua bênção e dar início aos trabalhos.

(Corumbá, 24/10/2011). Foto: Carmem Sílvia Moretzsohn Rocha.

Como processo descritivo da curimba, transcrevemos tanto as letras quanto os elementos melódicos e rítmicos dos rituais registrados. Alguns entrevistados também cantaram pontos e falaram sobre eles, o que é bastante significativo para o presente estudo. Em entrevista a um importante pai de santo de Corumbá, perguntei: "qual a importância da música nas religiões afro-brasileiras?” A resposta foi bem elucidativa:

Sim... muito bem... eu vou dizer pra você... nós costumamos dizer que... o leigo, o que vem ao terreiro, quando ele fala: "Ah, é uma música..." sim, pra vocês é uma música, pra nós... nós dizemos que é uma curimba. A curimba, realmente, é o que? Um ponto cantado, que expressa essa música que se escuta, às vezes, até mesmo no rádio, porque você vê que tem cantores de pagode, cantores do samba brasileiro, de raízes africanas que eles puxam certas coisas que são, vamos dizer assim... oriundas do terreiro. Eu vou dizer, seu Pena Branca, ele é denominado cacique Pena Branca, ele vem na Terra hoje, incorporou em mim, hoje... ele tem duas maneiras de se identificar-se... tá?... Costuma-se dizer que o médium desenvolve quando ele recebe o espírito pela primeira vez, o espírito ao entrar no corpo, na matéria, ele tem que deixar a dijina ${ }^{16}$ dele, o nome dele. Então, ou ele deixa o nome dele, ou ele risca o

\footnotetext{
16 "Nos candomblés bantos e na Umbanda, nome iniciático pelo qual o filho ou filha-de-santo será conhecido após a feitura. Do quimbundo dijina, nome" (Lopes, ibidem: 92).
} 
ponto que é os traços que corresponde à origem, à aldeia, ao nascimento, de onde ele veio,... entendeu? Então... ou então ele canta a curimba dele! entendeu? Então é isso que, muitas vezes, nesse cantar do orixá, é o orixá que faz as curimbas! E às vezes o orixá passa pra nós pais de santos também as curimbas que vêm na nossa intuição e que a gente escreve e depois a gente coloca a música em cima daqueles versos que eles expressam.

No principal terreiro estudado, a articulação com a identidade negra é um aspecto extremamente importante. O pai de santo da casa é neto de uma escrava, e os integrantes de sua família, que constituem uma associação, ganharam no presente ano o Certificado de Comunidade Quilombola da Fundação Palmares. O território onde está situado o terreiro é, portanto, parte deste quilombo onde moram várias famílias descendentes da referida escrava. Ednir de Paulo (IMNEGRA - ver nota 6) explicou-me que, embora a escravidão tenha, teoricamente, findado em 1888, isso não aconteceu uniformemente em todas as regiões do País. A mulher que deu origem à família mencionada chegou, ainda escrava, a Corumbá nos idos de 1920, estabelecendo-se em terras inóspitas e lutando por sua sobrevivência e de sua família. Ela, seu companheiro e seus descendentes são considerados verdadeiros desbravadores da região.

Além das letras, evidentes quando referem-se diretamente aos negros, à África, à Bahia ou explicitamente à escravidão e aos sofrimentos a ela relacionados, existem elementos estruturais da música que são considerados negros. Esses aspectos serão analisados posteriormente, no processo de elaboração da tese em curso.

Abaixo, transcrevemos duas toadas ${ }^{17}$ que quase sempre são cantadas uma seguida da outra no início dos trabalhos e, igualmente, nas festas da Tenda cujo chefe espiritual é o preto velho Pai Benedito. Após incensar a casa, o pai de santo e os médiuns cantam acompanhados do toque do atabaque (cujo ritmo está escrito na linha de baixo da partitura). A melodia do canto foi transcrita no primeiro pentagrama e a letra, acima. O pai de santo toca constantemente o adjá $^{18}$.

É possível notar as diversas referências ao universo dos negros. A curimba foi transcrita a partir do que foi cantado durante os rituais e, portanto, nenhum título foi anunciado antes. Decidimos dar um título às transcrições a fim de poder classificá-los com mais facilidade. Os preto é uma alusão clara aos negros e Aruanda refere-se à África e aos seus orixás. Ogum, famoso orixá e que também é conhecido como São

\footnotetext{
${ }^{17}$ Como os adeptos também se referem aos pontos cantados.

18 "É uma sineta de metal, usada em especial nos Candomblés e nos Xangôs (Recife) de origem ioruba, cuja finalidade é chamar os filhos-de-santo para reverenciar os Orixás" (Mattos, 2011: 31). Segundo um ogan entrevistado, o adjá também pode auxiliar na incorporação.
} 
Jorge e possuidor de um espírito guerreiro. Esse personagem foi homenageado por muitos compositores brasileiros, entre eles Zeca Pagodinho e Jorge Benjor.

O segundo ponto que é cantado em seguida refere-se ao Pai Benedito, chefe espiritual da casa. Enquanto é entoado, o pai de santo incorpora a entidade, iniciando, assim, o processo de incorporações e curas que decorrem desse importante momento. 
Os Preto Quando Vem de Aruanda \& Pai Bene dito
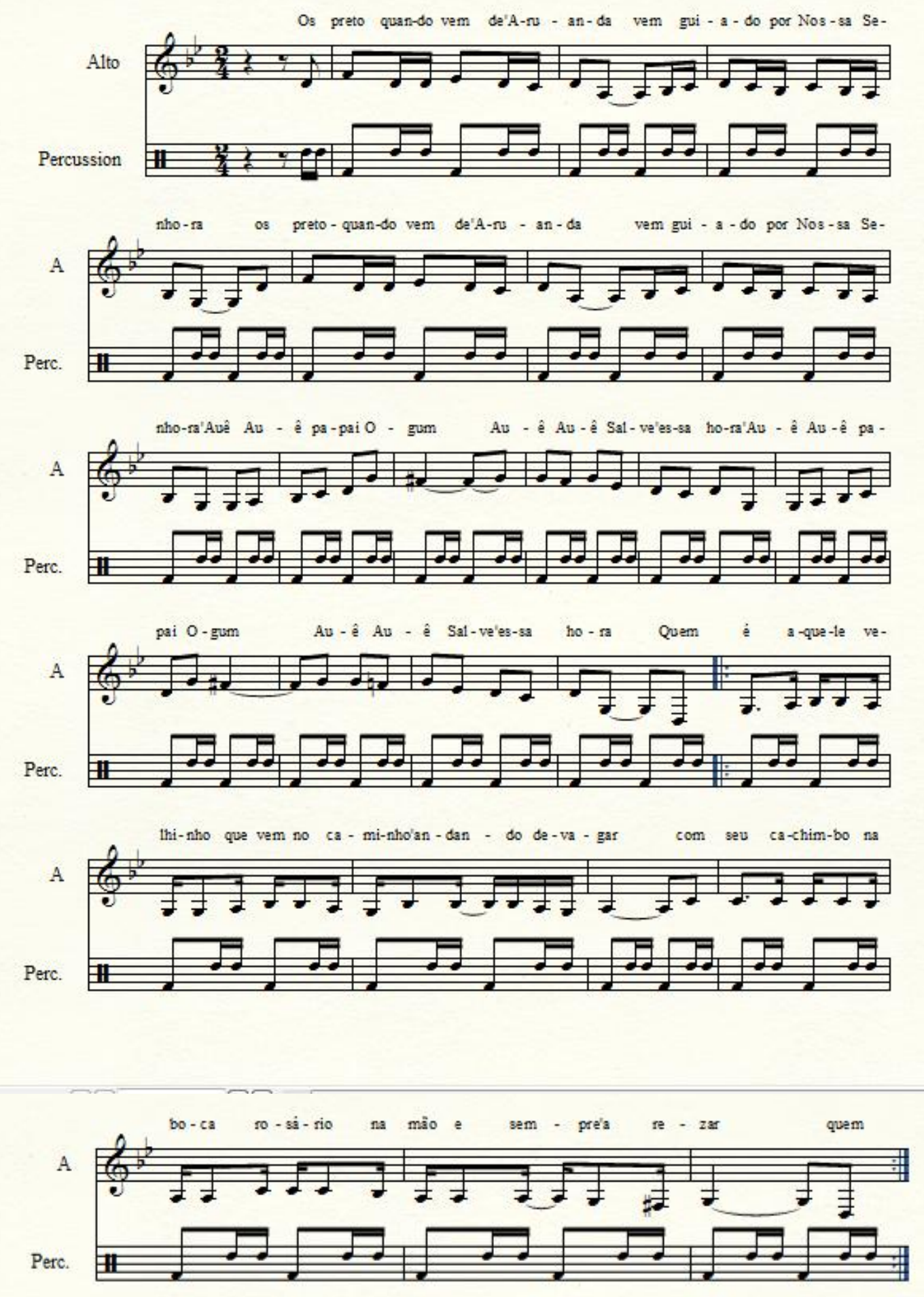

Transcrição: Carmem Sílvia Moretzsohn Rocha 
Sobre o papel das curimbas, foi-me revelado por uma das entrevistadas, cambone do principal terreiro pesquisado:

Tem os ponto que serve de proteção, de abertura do trabalho e pra se chamá os orixás... tem os ponto pra chamada dos preto velho, tem os ponto pros caboclo, pra eles podere vim... eles tão tudo ali mas tem que cantá pra eles vim. Todos os orixás tem que ter o ponto. Em geral, pra chamar todos os orixás em geral, né? Tem entidade, que cada entidade tem o seu ponto, né? Que quando uma pessoa começa a trabalhá na Umbanda, tem um tempo de gira ali... e quando as entidade começa a vir nas pessoas... então as própria entidade, faz o ponto dele... ele diz quem ele é, entendeu? Através do ponto, ele risca o ponto no chão... aí ele dá o nome do caboclo dele, né... se é o caboclo Sete Cachoeiras se é o caboclo Sete Flechas, então ele já canta o ponto dele... a entidade espiritual... eles canta o ponto dele, não é a gente que canta pra eles, ele já vem com o ponto deles, entendeu? Aí eles ensina a gente, eles fala como é que é o ponto deles e aí a gente vai começando a conhece o ponto, a cantá, aí chama o Silvino ${ }^{19}$ e Silvino bota uma batida de atabaque pra ver qual o som que vai ficá bom com aquele ponto ali que tá cantando.

$* * *$

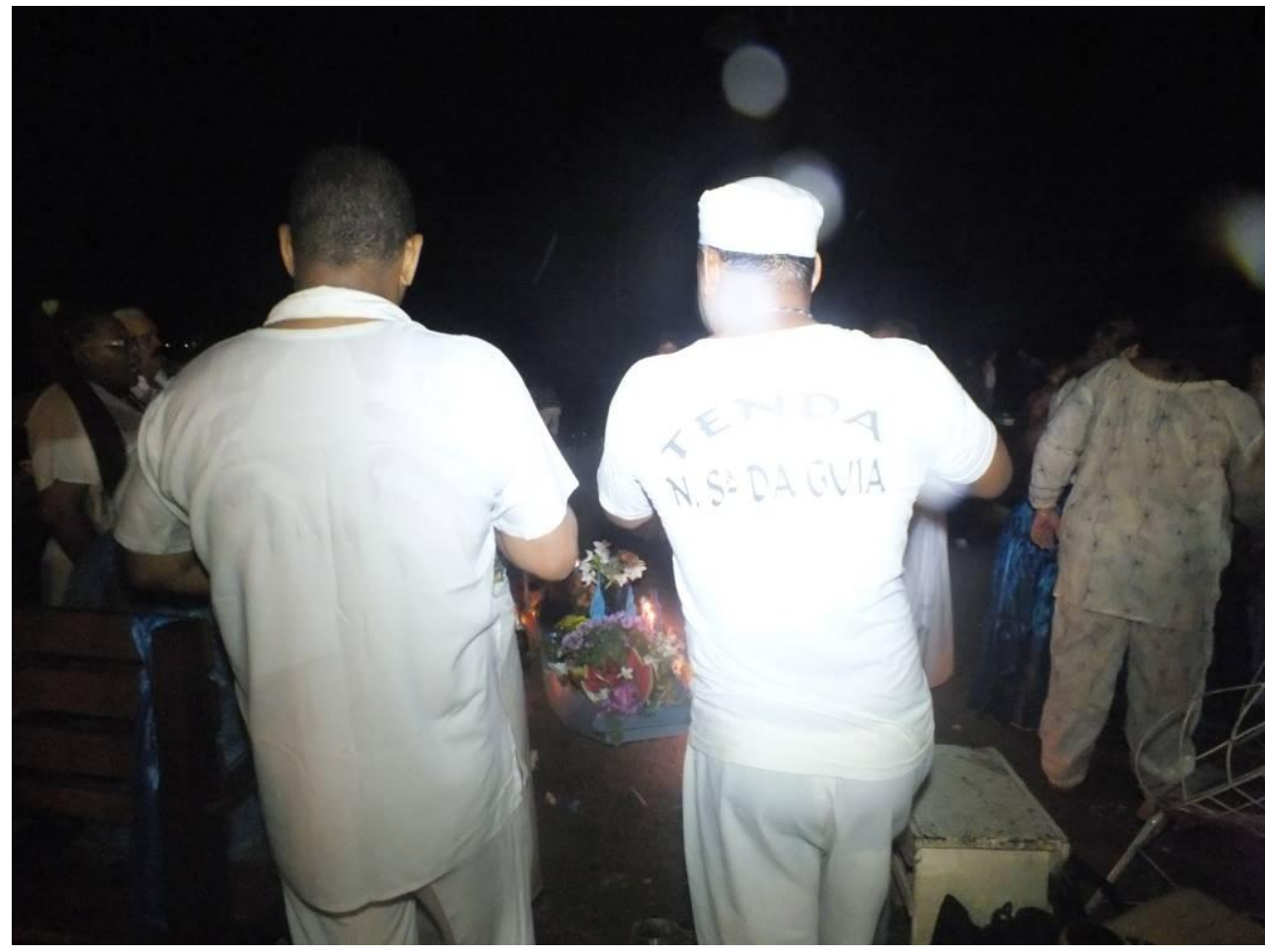

Figura 10 - No dia 30 de dezembro, os terreiros de Corumbá vão para a beira do rio Paraguai. Na foto, atabaqueiros tocam de frente para um pequeno barco com oferendas a Iemanjá

(Foto: Carmem Silvia Moretzsohn Rocha).

\footnotetext{
${ }^{19}$ Nome fictício, atribuído pela pesquisadora ao ogan da casa.
} 
Abaixo, a transcrição de um trecho da entrevista com um dos fundadores do terreiro, falando sobre o papel do ogan.

Entrevistado: o ogan de atabaque, na verdade, é um guardião também. Porque nós temos os guardiães espirituais e o guardião presente. Enquanto as entidades estão trabalhando, o presidente está trabalhando, o ogan está de frente pra porta de entrada. Então, se entrou uma pessoa, que a gente chama assim, não sei se é a melhor palavra, mas é assim que é conhecido na Umbanda, você, você entrou lá e você demanda contra o presidente da casa, o chefe da casa ou contra alguma entidade. Demandar é você jogar um ponto que não convém, desafiando a autoridade da casa, isso é demandar. Antigamente tinha muito isso.

Pesquisadora: uma pessoa de fora pode fazer isso?

Entrevistado: uma pessoa de fora que eu digo é assim: uma pessoa iniciada, que é de outra Tenda, aí tem conflito... lá não faz direito, vamos ver se lá faz direito... daí eu chego lá pra visitar e eu firmo o ponto, pra ver se você sabe, se você tá firmado. É um ponto de demanda, tá te desafiando. Se não for o presidente, o atabaque já some. Ele interrompe, pede agô, agô pra gente é... licença, né? Licença. Agô! (faz um gesto com a mão como se estivesse interrompendo o som) Segurou o ponto que tava sendo firmado, tá... segurou a corrente...

Pesquisadora: o ponto firmado seria...

Entrevistado: é a música. Porque existe o ponto riscado e o ponto firmado $\mathrm{O}$ ponto riscado é a identificação gráfica da órbita que aquela entidade trabalha. Qual o domínio dele. Se é mata, se é água, se é... sei lá... qual o domínio dele. Se é na linha da fé, se é na linha da... não sei, da orientação... porque cada um... são soldados. A gente trabalha pra uma determinada função. Se é cura... se é quebra de demanda, se é quebra de trabalho feito...

Os diversos aspectos articulados pela Umbanda são extremamente ricos e complexos. Em variados espaços urbanos e rurais, a religiosidade de matriz africana se faz presente. Na cidade, nos rios, mares, cachoeiras, congressos acadêmicos e terreiros, eterniza uma tradição que articula laços de sangue e espírito, manifestações artísticas e políticas como resistência a ataques frequentes ainda no século XXI. A música, através das curimbas, é um poderoso instrumento inserido nesse contexto e a identidade negra é cantada de variadas formas como elemento fundamental em sua construção.

Em setembro de 2012, apresentei no IX Congresso Internacional da Brazilian Studies Association (BRASA), em Champaign-Urbana, Illinois, alguns trechos de vídeos gravados durante o trabalho de campo. Vale ressaltar que o grupo autorizou-me a divulgar imagens em âmbito reduzido, pois luta pelo reconhecimento como comunidade quilombola e de suas tradições. Para eles, a pesquisa pode vir a contribuir com esse processo. A fim de acessar os significados de palavras e expressões que aparecem nas curimbas, recorri, principalmente, ao Novo Dicionário Banto do Brasil de Nei Lopes, que consta nas referências deste artigo. Considerando a noção de fato musical total, sugerida por Seeger (Velho, 1977: 45), farei a descrição de algumas cenas presentes nos vídeos mencionados. 
Vídeo 1: no primeiro quadro, vemos o pai de santo em frente à foto de sua tia, filha de uma escrava matriarca da família e famosa mãe de santo que recebia caravanas de ônibus lotados com brasileiros e estrangeiros. Ela atendeu personalidades como Xuxa, Chacrinha e Roberto Carlos, que chegou com seu iate Lady Laura, em busca de curas. Passou a seu sobrinho, neto da matriarca, a responsabilidade de dar continuidade a sua trajetória. A música para o preto velho Pai Benedito, chefe espiritual da casa cuja transcrição da música e da letra situam-se acima neste artigo, é cantada e o pai de santo incorpora a entidade, dando início aos trabalhos. A referência ao cativeiro é recorrente nas letras.

Vídeo 2: a curimba inicia falando do preto velho De Angola, "topônimo que se origina do quimbundo Ngola, 'nome do primeiro rei dos angolenses, ao qual atribuem a estes as doutrinas que fiaram seus usos e costumes"” (Alves, 1951: 945) In: (Lopes, ibidem: 29). Em seguida, mencionam o navio negreiro trazendo os africanos para trabalhar. Falam, também, do povo de Congo, "cujo nome deriva de um rio africano" (...) "onde os súditos pagavam seus impostos aos reis" (Lopes, ibidem: 82). A gira mencionada é a "roda ritual para cultuar as entidades" (Lopes, ibidem: 110). Referências à Bahia e à África, a presença dos chapéus de palha e dos cachimbos e a postura curvada dos médiuns são consonantes com o mundo dos pretos velhos, cultuados nos rituais.

Vídeo 3: esse vídeo faz referência à escravidão, ao excesso de trabalho do preto velho, ao senhor e ao tocar dos tambores. Fazem alusão, ainda, à senzala, "conjunto de alojamentos que, nas antigas fazendas ou casas senhoriais, se destinavam aos escravos. Do quimbundo, sanzala, lugar de habitação dos indivíduos de uma família” (Lopes, ibidem: 203). Cantam o nome de Oxalá, “o mais poderoso dos orixás” (Berkenbrock, 2007: 248), “identificado sincreticamente com Jesus Cristo" (Berkenbrock, ibidem: 249) e pode ainda ser chamado de Orixanlá, Orixalá ou Obatalá. Ogum também surge na letra da curimba, o orixá masculino do ferro, da mata e da guerra. Ouvimos: Saravá! , “saudação dos umbandistas, significando 'salve!'. Bantuização do português salvar, saudar" (Lopes, ibidem: 202). Referem-se, ainda, a Xangô, orixá masculino do fogo, do trovão, do raio, da guerra e da justiça. O nome Xangô também é utilizado para designar a religião afro-brasileira de tradição Yoruba praticada em Recife. O grupo canta que: "negro já foi escravo e já serviu, mas que hoje é tratado como doutor", mostrando a mudança do passado para o presente; conclamam: "não batam no lombo do negro, senhor, negro é humano, negro também sente dor". Aqui vemos que clamam pela 
humanidade do negro. Lembramos que para justificar os maus tratos que os escravos negros sofriam, a Igreja Católica afirmou que "negro não tinha alma". Em outro trecho, entoam: "no tempo da escravidão, quando o senhor me batia, eu rezava por Nossa Senhora, senhor, como a chibata doía!” Segundo Lopes, a palavra chibata utilizada significa "vara delgada para fustigar ou chicote". A etimologia é controversa. O autor Nascentes faz derivar de chibo (a chibata seria a vara usada pelo pastor para fustigar o chibo - bode não capado). Já Raymundo vê como bantuização do português espada confirmado pelo Dicionário Complementar Português-Kimbundu-Kikongo de Maia que confirma ao consignar como significado espada com as seguintes designações em kimbundo: xipata, xibata, sipata, songolulu, njangu, kimpumpu, mbanji (Lopes, ibidem: 78). Nesse vídeo, são recorrentes as alusões ao sofrimento vivido pelos escravos negros.

No quarto vídeo, exaltam o orgulho e a identidade negra. O terreiro é composto por uma típica família de santo, onde os laços de sangue e de santo se misturam, perpetuando uma tradição religiosa em que a identidade negra tem um importante papel. O vídeo dá destaque para a mulher que está próxima ao pai de santo, sua mãe de sangue e filha de santo. Essa família ganhou no presente ano o Certificado de Quilombo da Fundação Palmares de comunidade quilombola.

A presidenta do IMNEGRA, importante personagem neste processo, relatou-me que a matriarca da família chegou a Corumbá nos idos de 1920, ainda escrava. Apesar de o fim oficial da escravidão ter sido em 1888, essa instituição permaneceu ainda por muitos anos nos rincões do país. Essa família é uma prova inconteste desse fato. O pai de santo, com apenas 30 anos, é neto de escrava! Ednir luta pelo reconhecimento de famílias como remanescentes de quilombos e conseguiu esse feito inédito em Corumbá.

\section{Confissões antropológicas}

O campo é um desafio único e intransferível para o antropólogo. Não há como não se deparar consigo, com sua própria identidade, suas experiências, frustrações e expectativas. Buscamos sentido, significados em nós e nos outros. Como chegamos até aqui? Para onde vamos? Questões óbvias e, ao mesmo tempo, complexas, com as quais temos que lidar quando nos lançamos ao campo.

O que representa tudo isso, afinal? Campo, objeto, aspectos antropológicos que nos levam à relação com o outro. Complexa relação sujeito-objeto, repleta de intersubjetividades entrelaçadas a construir a história presente, apontando, igualmente, 
para o futuro. Imbricação de tradições, vidas, paixões, construções e desconstruções, relações de poder, mistérios, buscas e realizações. Sem Dúvida, não é fácil, mas, por isso mesmo, fascinante! Abraçamos o conhecimento adquirido como porto seguro. No entanto, o mundo de significados a decifrar chega a ser assustador! Duas questões simples e, ao mesmo tempo muito profundas: como cheguei até aqui e para onde vou? A seguir, compartilho um pequeno trecho de meu diário de campo, com adaptações, a fim de melhor compor o quadro de elementos já esboçados. Os nomes dos personagens foram alterados, a fim de resguardar suas identidades.

Corumbá, 23 de outubro de 2011

-- Você gosta de quiabo?

-- Eu adoro quiabo!

-- Com ou sem baba?

-- Ué, e existe quiabo sem baba?

-- Claro! E é muito mais gostoso do que o com baba!

-- É mesmo?

-- Minha filha sabe fazer um quiabo sem baba muito bom. Você precisa provar!

-- Huumm... eu adoraria!

Esse é o trecho de um pequeno diálogo travado entre mim e Joice no dia 21 de outubro, sexta-feira, após os trabalhos que nesse dia, terminaram mais tarde, por volta das 23 horas. Era dia de Exu e Pomba Gira. Foi a segunda reunião desse tipo em que estive presente. Na primeira, Exu mandou Joice me oferecer cerveja. Foi no dia 30 de setembro e eu não podia beber, pois tinha tomado quatro vacinas. Agradeci, joguei um pouquinho no chão, como me foi ensinado por Daniel e manda a tradição, entreguei o copo para Dolores e expliquei: não posso beber. Tomei quatro vacinas hoje! Ela sorriu e recebeu o copo.

Voltando ao dia 21 de outubro. Exu ofereceu-me cerveja duas vezes e aceitei. Estava muito calor e estava com sede. A cerveja corria solta. Dei duas goladas bem grandes! Para segurar a caneca da mão de Exu enquanto filmava, tive que pegar de qualquer jeito, pois não deu tempo de interromper a filmagem. Após beber, voltei a focalizar as cenas que achava interessantes. Lá fora, o pessoal começou a servir comida, mas não aceitei. Achei que eles só ofereceram por educação. Aí, Dolores perguntou: mas, nem cerveja? E respondi: ah... cerveja, eu aceito! Logo em seguida, Joice me perguntou sobre o quiabo. Disse que um dia iria me convidar para comer e eu disse que aceitaria: "É só chamar!”, respondi. 
Nessa mesma noite, uma moça que não nunca tinha visto mas cantou e tocou junto com Sebastião, o ogan da casa, e outro rapaz, perguntou-me logo após a finalização dos trabalhos: "para onde vão essas fotos?" Expliquei que estava fazendo uma pesquisa sobre religiões afro-brasileiras e que escreveria uma tese sobre o assunto e, por esse motivo, era importante registrar tudo. Ela me disse que o pai dela tinha um terreiro de candomblé e me convidou para uma festa no dia 8 de dezembro. Trocamos telefones.

Nessa mesma noite, Dolores me contou que, embora não quisesse, teria que entrar na gira. Isso significa que ela será iniciada como girante, ou seja, aprendiz de médium. Ela disse que não queria isso, por causa da responsabilidade, mas que não teria jeito, pois estava sendo chamada já há algum tempo. Contou-me ainda que falou sobre mim com a Ednir de Paulo, pessoa responsável pelo processo de registro da família como comunidade quilombola. Posteriormente, encontrei Ednir algumas vezes. No primeiro dia, foi em frente ao terreiro e ela perguntou o que estava fazendo. Ao saber que eu pertencia à comunidade acadêmica, aprovou a pesquisa.

As biografias, afinidades, interesses, objetivos, condições, acasos e limitações de todos os indivíduos envolvidos no processo de uma pesquisa antropológica abarcam uma complexa gama de elementos inseridos na comunicação que se estabelece. Faz-se necessário, além de o esforço intelectual, colocar à disposição, o próprio corpo, a sensibilidade, incluindo todos os sentidos e sensações, sem perder o rumo da trajetória que nos levou até aquele lugar e àquelas pessoas. A entrada de um pesquisador em um grupo é, inevitavelmente, uma invasão. No entanto, pode coadunar-se com os interesses e intenções desse mesmo grupo. Por vezes, há cobranças ou ciúmes. Certa vez, ouvi do pai de santo do principal terreiro que pesquisei em relação a uma festa que iria ocorrer: “você não vai a outro lugar não, viu? Venha aqui!” Já estava, na verdade, nos meus planos comparecer a sua casa, mas percebi a importância e responsabilidade expressa em suas palavras.

\section{Breves considerações}

Gilroy (2001) denomina "política da transfiguração" aquela que enfatiza o surgimento de desejos, relações sociais e modos de associação qualitativamente novos no âmbito da comunidade racial de interpretação e resistência e também entre esse grupo e seus opressores do passado. Ela aponta especificamente para a formação de uma 
comunidade de necessidades e solidariedade, que é magicamente tornada audível na música em si e palpável nas relações sociais de sua utilidade e reprodução culturais.

Embora tenhamos consciência de que é inviável e inadequado essencializarmos a noção de raça, faz-se necessário, no entanto, abrirmo-nos à premente necessidade de reparação em relação às populações afrodescendentes, considerando o triste passado e suas sequelas ainda presentes.

A intenção da pesquisa em curso e, ainda, deste artigo que se encerra, com as devidas proporções, é conciliar diversos objetivos, entre eles, oferecer à comunidade acadêmica uma narrativa ou, segundo Clifford, uma alegoria, considerando que "os textos etnográficos são inescapavelmente alegóricos" (Clifford, 2011: 60) que constitua uma contribuição capaz de aprofundar os debates em voga através de variados elementos como o próprio texto escrito, o universo sonoro e o contexto em que está inserido, elementos imagéticos e outros que possam representar a relevância das tradições vividas por indivíduos e grupos consonantes com este estudo. Acima de tudo, que a realização deste trabalho possa significar um retorno positivo para todos os foram envolvidos nesse processo.

Buscamos trazer à tona as práticas, os discursos em diferentes formas e os significados atribuídos, fundamentalmente, pelos atores sociais que as vivenciam e estabelecer um contraponto polifônico com algumas áreas da antropologia, em especial, a etnomusicologia e a antropologia visual.

Partindo do pressuposto de que muitos foram os esforços empreendidos por alguns setores da sociedade brasileira no sentido de vilipendiar aqueles oriundos de raízes afrodescendentes, desejamos colaborar com a construção de um contexto de valorização dessas populações, que se intensifica nos mais variados espaços, desde a própria academia até os recônditos urbanos e rurais, nas artes, no mercado de trabalho, nas escolas e nas religiosidades.

\section{Referências}

AMARAL, Rita. Xirê! O modo de crer e de viver do candomblé. Rio de Janeiro: Ed. Pallas, 2002.

- SILVA, Vagner Gonçalves da. "Cantar para subir - um estudo antropológico da música ritual no candomblé paulista". In: Religião e Sociedade, v.16, n.1/2. Rio de Janeiro: ISER, 1992b. Disponível em: www.n-au.org/Amaral\&Silva1.html . 
; SILVA, Vagner Gonçalves da. "Religiões afro-brasileiras e cultura nacional: uma etnografia em hipermídia”. In: Revista Pós Ciências Sociais, v.3, n.6, jul/dez. São Luiz: UFMA, 2006. p 107-130.

BASTIDE, Roger. O candomblé da Bahia: rito nagô. São Paulo: Nacional, 1978.

BERKENBROCK, Volney J. A experiência dos orixás: um estudo sobre a experiência religiosa no Candomblé. 3. ed. Petrópolis: Vozes, 2007.

BERND, Zilá. "O que é negritude". In: Coleção Primeiros Passos, n.209. São Paulo: Editora Brasiliense, 1988.

CARVALHO, José Jorge de. Ritual and music of the Sango cults of Recife, Brazil. 1984. Thesis (PhD Anthropology), The Queen's University, Belfast, 1984. (mimeo).

CENTRO DE POLÍTICAS SOCIAIS / FUNDAÇÃO GETÚLIO VARGAS (CPS/FGV). \% Afro-Brasileiros por Municípios - Brasil 2000. Disponível em: www4.fgv.br/cps/simulador/site_religioes2/RANKINGS. Acesso em: 04/03/2012.

CLIFFORD, James. A experiência etnográfica: antropologia e literatura no século XX. Organizado por José Reginaldo Santos Gonçalves. 4. ed. Rio de Janeiro: Editora UFRJ, 2011.

CONDURU, R. L. T. "Das casas às roças: comunidades de candomblé no Rio de Janeiro desde o fim do século XIX". In: Topoi, v. 21. Rio de Janeiro: UFRJ, 2010. p. 178-203.

CONTINS, Marcia. "Religião, etnicidade e globalização: uma comparação entre grupos religiosos nos contextos brasileiro e norte-americano". In: Rev. Antropol., v.51, n.1. São Paulo: USP, 2008. $\quad$ Disponível em http://www.revistasusp.sibi.usp.br/scielo.php?script=sci_arttext\&pid=S003477012008000100003\&lng=pt\&nrm=iso . Acesso em: 27 de maio de 2012. CORRÊA, Norton. O batuque do Rio Grande do Sul. Porto Alegre: Ed. UFRGS. 1992. CORREIO DO ESTADO. Religiões afro-brasileiras chamam atenção para regulamentação. Disponível em: http://www.correiodoestado.com.br/noticias/religioesafro-brasileiras-chamam-atencao-para-regulamentaca_117111/. Acesso em: 04 de março de 2012.

FERRETTI, Mundicarmo. Desceu na Guma: O caboclo do tambor de mina no processo de mudança de um terreiro de São Luís - a Casa de Fanti-Ashanti. São Luís: SIOGE, 1993.

FERRETTI, Sérgio. Querebentam de Zomadonu: Etnografia da Casa das Minas. São Luís: Edufma, 1986.

GILROY, Paul. O Atlântico Negro: modernidade e dupla consciência. Tradução de Cid Knipel Moreira. São Paulo: Ed. 34; Rio de Janeiro: Universidade Cândido Mendes, Centro de Estudos Afro-Asiáticos, 2001.

LOPES, Nei. Novo dicionário banto do Brasil: contendo mais de 250 propostas etimológicas acolhidas pelo Dicionário Houaiss. 1a ed. Rio de Janeiro: Pallas, 2006.

MAGGIE, Yvonne. Guerra de orixá: um estudo de ritual e conflito. Rio de Janeiro: Zahar Editores, 1975.

MATTOS, Sandro da Costa. O livro básico dos Ogãs. $2^{\mathrm{a}}$ ed. São Paulo: Ícone, 2011. MIRANDA, Dina Karla. IMNEGRA comemora Dia Nacional da Consciência Negra. Disponível em: http://capitaldopantanal.com.br/cdp/politica/10013-instituto-da-mulhernegra-do-pantanal-comemora-dia-nacional-da-consciencia-negra-.html . Acesso em: 04 de março de 2012.

MOTTA, Roberto. Meat and feast: the xango religion of Recife, Brazil. New York: Columbia University, 1988.

NERI, Marcelo Côrtes. Novo Mapa das Religiões. Rio de Janeiro: FGV, CPS, 2011. 
OLIVEIRA PINTO, T. de. "Som e música. Questões de uma antropologia sonora". In: Revista de Antropologia, v.44, n. 1. São Paulo: USP, 2001.

ORO, Ari Pedro (Org.). As religiões afro-brasileiras do Rio Grande do Sul. Porto Alegre: UFRGS, 1994.

PREFEITURA MUNICIPAL DE CORUMBÁ. Dados geográficos. Disponível em: http://www.corumba.ms.gov.br/canal.php?c=45 . Acesso em: 05 de março de 2012.

RIBEIRO, René. Cultos afro-brasileiros do Recife: um estudo de ajustamento social. Recife: Instituto Joaquim Nabuco, 1952.

RIO, João do. As religiões do Rio. (1904). Rio de Janeiro: José Olympio, 2006.

RODRIGUES, Raimundo Nina. O animismo fetichista dos negros bahianos. Rio de Janeiro: Civilização Brasileira, 1935.

SEGATO, Rita Laura. Santos e daimones. Brasília: UnB, 1995.

SILVA, Vagner Gonçalves da. "A crítica antropológica pós-moderna e a construção textual da etnografia religiosa afro-brasileira". In: Cadernos de Campo, ano 1, n.1. São Paulo: USP, 1992. p. 47-60.

. Orixás da Metrópole. Petrópolis: Vozes, 1995.

. O Antropólogo e sua Magia: São Paulo: EDUSP, 2006.

VELHO, Gilberto (org.). Arte e sociedade: ensaios de sociologia da arte. Rio de Janeiro: Zahar Editores, 1977.

VERGER, Pierre. Orixás: Deuses Iorubás na África e no Novo Mundo. São Paulo: Círculo do Livro e Editora Corrupio, 1981.

Recebido em: 31/10/2012

Aprovado em: 17/12/2012 